\title{
To tårn tett i tett: Hamar bispedømmes regionale håndverkermiljø $\mathrm{i}$ middelalderen
}

Høymiddelaldersamfunnet i Norge hadde to statsmakter: kongen og kirken. Konflikten mellom dem tok for alvor til da kong Sverre i 1184 krevde at kongen skulle stå over kirken. I Hamar bispedømme var biskopenes opprørsparti baglerne, sammen med kongens verdslige fiender, samlet som en trussel mot kong Sverre. Utover på 1200-tallet ble striden mellom konge og biskoper i Norge intensivert. Konflikten resulterte blant annet i en krangel mellom biskop Pål (1232-1252) på Hamar og kong Håkon Håkonsson (1217-1263) om rettighetene til Helgøya i Mjøsa, sørvest for Hamar. Tidlig på våren 1234 reiste kongen fra Sogn over til Opplandene for å ordne opp i tvisten med biskopen, da han mente at baglerhøvdingen Inge uten rett hadde gitt bispestolen rettigheter til Helgøya. Som et motsvar lot Håkon Håkonsson derfor bygge et steinkastell, Mjøskastellet, på Steinsholmen nord i Mjøsa for å kontrollere båttrafikken fra nord og sør. Mjøskastellets plassering var strategisk. Kongen kunne derfra også kontrollere flere viktige innlandsveier som førte til Nidaros over Dovrefjell (Eriksson 1995:134-136).

Biskop Pål av Hamar dro deretter til pave Gregorius IX i Roma og klaget til ham om kongens «overgrep» (DN I, nr 13). ${ }^{1}$ Paven tok biskopens side og anklaget kongen for «på denne kirkes eiendom, som du på alle måter søker å undertrykke, har bygget fra nytt av en borg (kastell) mot denne biskopens vilje, idet du behøver dens (kirkens) visse grunneiendommer» (etter Fischer 1928:2). Gjennom byggingen av Mjøskastellet manifesterte Håkon Håkonsson sin makt over det indre Østlandet som opposisjon til biskop Pål på Hamar i de pågående borgerkrigene (Fischer 1951:215). Under borgerkrigen var kongens stilling svak på Opplandene, hvor baglerne var dominerende. Gerhard Fischer (1928:1, 1951:215) fremhever at byggingen av Mjøskastellet var ment å konsolidere kongens makt her. Til tross for det omtales ikke Mjøskastellet ellers som en del av stedene med krigerske handlinger på Østlandet i perioden, og det er underlig, spesielt med tanke på ribbungfeidene i 1220-årene. Mjøskastellet sees videre i sammenheng med biskopene Pål og Peters (1253-1260) bygging av et frittliggende tårn på Hamar rundt 1250, som et svar på den kongelige maktdemonstrasjonen. Jeg tror at Pål påbegynte dette byggeprosjektet, og at borgen med tårnet ble sluttført av Peter, slik Peter er beskrevet som byggherre i Jens Nilssøns visitasbøker og reiseopp-

Kontakt: Kristian Reinfjord, e-post: kristian.reinfjord@annomuseum.no 
tegnelser 1574-1597. Hva er sammenhengen mellom disse bygningene, og kan de knyttes til ett regionalt håndverkermiljø på Østlandet?

I artikkelen presenteres en eksempelstudie med utgangspunkt i Hamar bispeborgs tårn og i Mjøskastellet, og jeg argumenterer for at samme håndverkere var involvert $\mathrm{i}$ begge arbeidene. Domkirkenes håndverkere, organisert i bygghytter, slik som på Hamar (jf. Reed 2005), etablerte regionale miljøer som videre påvirket lokale murere i byggingen av for eksempel sognekirker og profane steinbygg. Dette til tross for at oppføringen av tårnene inngikk i en konflikt mellom kongen og biskopen. Om regionale håndverkere kunne ta både profane og kirkelige oppdrag, understreker det steinhåndverkerens sentrale og uavhengige rolle i middelalderen. Jeg søker å vise hvordan regionale håndverkere kommer til syne i tårnenes utforming og $\mathrm{i}$ tekniske detaljer, og hvordan bygningenes materialitet inngikk $\mathrm{i}$ kirkens og kongens konsolidering av Østlandet. Jeg vil diskutere hvordan man skal forstå håndverkets spredning fra bygghytter i sentrum til periferiene, og om man kan lese ulike bygghytter ut av det arkeologiske materialet. I materialet, som består av utvalgt steinarkitektur i Hamar bispedømme, observerer jeg håndverkernes etterlatte signaturer i bygningsuttrykk, dekor, materialbruk, behandling av stein og opplegg av murer. Også råstoffbruk og mørteltilslagenes korning viser distinkte spor etter regionens håndverkere. Å påvise regionale håndverkere kan gi ny kunnskap om kirken og kongen som byggherrer og om håndverkets organisering, men også om bygningenes utforming og strukturers agens, samt opphav til deres uttrykk og politiske utgangspunkt. I denne sammenheng synes dermed materialet på Østlandet fra tidlig 1200-tall og utover mot 1500-tallet å være spesielt interessant.

\section{Regional steinbygging og murhåndverkere i Hamar bispedømme}

Hamar bispedømme opplevde stor byggeaktivitet med stein fra andre halvdel av 1200-tallet. Til tross for lite steinbygging i øvrige landsdeler etter 1250 ble det under Hamar-biskopen Peter, som døde i 1260, oppført en bispeborg, et kastell, og et profant steinhus på Gran. Videre ble domkirkens kor utvidet, og kirkene Ringsaker, Stange, Gran og Hoff påbygd. Hamar-biskopen bygget også sin gård på Storøya i Tyrifjorden i denne perioden (Hommedal 1999). Flere hvelvede steinkjellere er kjent fra etter 1250, både på Domkirkeodden og ved kirkene Hoff, Ringsaker og Gran. I tillegg ble kastellet på Steinsholmen i Mjøsa oppført for Håkon Håkonsson rundt 1230. Bygningene viser en relativt stor byggevirksomhet i Hamar-biskopens region, og det er interessant å studere bygningene, her representert ved Hamar bispeborgs tårn og Mjøskastellet, med tanke på deres homogene utforming, materialbruk og håndverksteknikk. Kan disse bygningene komme fra ett håndverksmiljø?

Håkon Christie (1969) og Hans-Emil Lidén (1981) med flere har tolket det dithen at katedralene samlet håndverkere fra utlandet, som spredte impulser videre rundt i regionene. Å etterspore håndverkerne kan gi ny kunnskap om bygningenes utforming og struktur, samtidig som opphavet til bygningenes uttrykk kartlegges i en regional kontekst hvor biskopen og kongen var rivaliserende byggherrer. Bygninger som er oppført innenfor samtidige historiske kontekster, styrker hypotesen. Om bygninger er av ett håndverkermiljø, bør de sammenfalle kronologisk. Det synes jeg man kan lese ut av det arkeologiske materialet, slik det i artikkelen fremgår i følgende komparative analyse av stilistisk utforming, håndverksteknikk og materialbruk. 
I min studie definerer jeg avgrensningen for håndverkernes virkeområde basert på deres arbeidsgiver, biskopen. Hamar bispedømme utgjør således den regionale avgrensningen for håndverksmiljø i denne sammenheng. Slik Irene Baug (2016) har foreslått i sitt arbeid med regionalitet $\mathrm{i}$ arkeologiske analyser, kan en avgrensning være politisk-administrative regioner, økonomisk funksjonelle regioner eller identitetsregioner. Jeg vil ikke diskutere regionalitet og avgrensninger inngående her, men definerer avgrensningen for håndverkernes virkeområde basert på deres antagelige arbeidsgiver biskopen. Hamar bispedømme faller inn under i alle fall de to første av Baugs kategorier. Østlandet var i middelalderen et særpreget område påvirket av Skagerak, og siden vikingtiden og inn i middelalderen under danskekongens interesseområde. Det er påpekt at Østlandet var et selvstendig «rike» i nær kontakt med Danmark i opposisjon til Sverre-dynastiet (Ekroll 2004:66). Opplandene, som omfattet Hamar bispedømme, var baglerrike i opposisjon til kong Sverre. Opposisjonen på Østlandet var en allianse mellom kirken og kongen, hvor hamarbispen Tore (1190-1198) og Ivar Skjalge (1199-1221) var sentrale aktører som del av baglerpartiet. Her var det altså samhandling mellom de regionale kongene og biskopen, og bygghyttene på Østlandet var derfor kanskje kjent med oppdrag fra både geistlige og kongelige.

Utstrekningen av Hamar bispedømme fulgte i stor grad de opprinnelige grensene for lagdømmene (Brendalsmo 2015:46). For Hamar gjelder det Eidsivating. Middelalderens Norge hadde en stor geografisk utstrekning, og veier og kommunikasjonslinjer var lite utviklet, så variasjoner i regional materiell kultur vil forekomme. Regionene viser sine materielle nyanser. Påfallende regional er bruken av steintyper i middelalderens kirker, som kan knyttes til regionale håndverksmiljøer. Blant steinkirkene finnes geografiske forskjeller i materialbruken som samsvarer med de fire eldre bispedømmene. Hamar bispedømme samsvarte i store trekk med Eidsivatings lovområde med unntak av Solør og Romerike. Innen Norges fire eller fem lagdømmer i middelalderen har Øystein Ekroll (2008) vist separate områder for materialbruk i middelalderens kirkebygg. Dette antyder at det ble etablert bygghytter for hver region, og at de samme murermiljøene sto bak byggingen innen sine distrikter og perioder. Naturgitte forutsetninger og rammer ligger til grunn, men utnyttelsen av for eksempel byggematerialer er kulturbetinget. I Hamar bispedømme og spesielt rundt Mjøsa er det benyttet kalkstein, som er enkel å forme og lett tilgjengelig. Kalkstein kan også brennes for produksjon av mørtel sammen med tilslag av for eksempel mjøsgrus, som kjennetegnes av innslag av sorte alunskiferkorn, som vi finner rundt Hamar. Kalksteinen er brutt i lokale steinbrudd, og det er påvist flere slike i nærheten av Hamar-kaupangen: i Furuberget, i Bergevika og på Domkirkeodden. Stein ble også eksportert på nærliggende elver, som Glomma og Vorma. Kalksteinstradisjonen skiller seg fra granittbruken langs kysten i Vestfold og Sør-Norge og fra klebersteinsbruken i Nidaros erkebispedømme og på Vestlandet. Også utsmykkingen og utformingen av steinkirkene følger tilsvarende mønster (Ekroll 2008:29). Bak mønstrene i steinarkitekturen sto håndverkere som gjorde bevisste valg i prosesser med bearbeiding av stein til mur og bygninger. Disse menneskene er lite omtalt i skriftlige kilder, men deres handlinger og beslutninger er lesbare i deres materielle levninger. 


\section{Murhåndverkets organisering og impulsspredning}

Håndverkere som bygde hus i stein, ble i tidlig middelalder omtalt som steinmeistari, steinsmider, grjótmeistari eller grjótsmidr (Stigum 1967:20). På grunn av lite kildetilfang har murhåndverket og håndverkerne vært en liten del av diskursen omkring forståelsen av middelalderens steinarkitektur, selv om de omtales i oversikter (Lidén 1974; Svanberg 1983; Ekroll 1997; Svanberg 2013). Kilder til middelalderens murhåndverkere finnes i bygningene selv. Håndverkerne i byene organiserte seg i laug for å fremheve sine rettigheter (Fischer 1965:530). Steinhuggere og murhåndverkere var knyttet til enkeltbygninger som katedraler, hvor fagmiljøer oppsto i form av bygghytter. Fagmiljøene hadde egne konstitusjoner og regler, slik de vises i manuskriptene Regius MS i England fra 1390 og Cooke MS fra omkring 1430 (Fischer 1965:530). Ved Strassburgdomen kjenner man også til slike regelmanuskripter, som dens Steinmetzordnung fra 1459, men bygghytten der var allerede i 1277 blitt Haupthütte etter keiserlig privilegium, som viser at bygghyttene var hierarkisk systematisert med en hovedhytte og mindre, underordnede bygghytter. Dokumentene viser at regionale miljøer var forankret og formalisert i middelalderen, kanskje også i Norge, som videre kan tyde på at de ulike miljøene fikk sine karakteristiske uttrykk som materialiserte seg $\mathrm{i}$ bygningene selv.

Lidén (1981:46-48) hevder at murhåndverket kom fra utlandet, da dette var en ny byggeteknikk i tidlig middelalder i Norge. Muring av kirker og andre større anlegg var en komplisert prosess som ble organisert i bygghytter, ofte i tilknytning til bispesetene, med kontinuerlig arbeid i perioden med steinbygging i Norge fra omkring 1150 til ut på 1300-tallet. Katedralene ble vedlikeholdt og påbygget, og biskopene engasjerte håndverkere på permanent basis (jf. Sæther 1998). Bygghytter fantes i Stavanger, Trondheim, Oslo, Hamar og Bergen. Lidén (1981:47) ser også for seg en kongelig bygghytte i Oslo og Bergen omkring 1300. Bispesetenes bygghytter har vært premissleverandører for utformingen av steinarkitekturen gjennom kanalisering av utenlandske impulser. Utenlandske impulser, spesielt fra England, spredte seg fra domkirkenes bygghytter til regionene. Regionale uttrykk oppsto i steinbygningens uttrykk ved spredning og tilpasning, og Lidén (1981:47) omtaler ulike utenlandske impulser i katedralene i Trondheim, Bergen og Stavanger som «entydig tilknytning til bestemte miljøer». Håndverkernes særegne uttrykk kommer til syne i kirkenes utforming. I det ligger en forståelse av at håndverket sprer seg fra bygghytter i sentrum til periferiene, og at de ulike bygghyttene kan spores i det arkeologiske materialet gjennom komparative analyser. Resultatet av analysen antas å være at hver bygghytte hadde sine distinkte uttrykk, som speiler like forutsetninger og tankeprosesser.

\section{Komparative eksempler innenfor Hamar bispedømmes region}

For å påvise hvordan håndverkermiljøer koblet til Hamar domkirkes bygghytte kan ha vært involvert i samtidige prosjekter, vil jeg gjøre en komparativ analyse av utvalgte bygninger i regionen. Arkitektur spilte en viktig rolle i middelaldermenneskets bevissthet, og likhet mellom bygninger og kopier var en viktig del av arkitekturens persepsjon. Richard Krautheimer fremhever videre hvordan middelaldermennesket så likheter i bygninger, og hvordan bygningenes ikonografi fremhevet bygningers innhold ved å spille på eller etterligne kjente former og uttrykk (Krautheimer 1942:2). Assosiasjoner og meningsinnhold ble videreført, forsterket eller endret. Slik ble byggherrens intensjoner bak bygningene forster- 
ket ved å imitere kjente bygninger med kjent meningsinnhold. Våre moderne øyne kan vanskelig se hvilke trekk ved to bygninger som var sammenlignbare i middelalderen.

Krautheimer eksemplifiserer sin hypotese med imitasjoner av Den hellige kirke i Jerusalem, hvor geometrisk form som rotunder og ulike polygoner i bygningskroppene er avgjørende. For eksempel er konnotasjonene omkring et korsformet grunnplan et fundamentalt grep i kirkearkitekturen, som er med på å knytte bygninger sammen. Andre bygningsformer kunne være sirkelen som et symbol på kirken, eller ulike nummerkonnotasjoner som åtte og tolv (Krautheimer 1942:8-9). Bygninger er ikke identiske, men tar opp i seg elementer fra en prototyp som er essensiell for at vi skal kunne identifisere utgangspunktet som imiteres. Prinsippene synes gyldige for middelalderarkitektur i Norge, som for eksempel tårnene i Hamar bispedømme.

Spesielt relevant i denne sammenheng synes tårnets ikonografiske kjennetegn å være, med sine høye murer, inngangsportaler og utsmykkede vinduer. Kongens tårnbygging var spesielt provoserende, ikke bare på grunn av at bygningen befestet et sentralt område, men også i kraft av sin bygningstype. Fra 1200-tallet finnes det i Europa eksempler på forsøk på regulering og lovfesting av tårnbygging (Kühtreiber 2014:42). En trengte her kongens tillatelse til å bygge høyere enn to etasjer, eller til å bygge en ringmur høyere enn at en rytter kunne strekke seg over muren. Det er ikke kjent slike reguleringer fra Norge, men de europeiske lovene forteller noe om holdningen til bygging av slike tårn i samtiden. Tårn var spesielt potente symboler for konsolidering av makt. Frittstående tårn er sjeldne fra middelalderens Norge, og er kun bevart i Mjøskastellet og i Hamar bispeborg (figur 1).

Tårnet var i samtiden ansett som en høystatusbygning, hvor bygningstypen og formen var med på å røpe byggverkets funksjon og meningsinnhold. Slik kunne bygging av tårn, en type som var knyttet til makt, være med på å stadfeste en posisjon i landskapet, slik Mjøskastellet og tårnet i Hamar bispeborg er eksempler på. I konflikten mellom kirke og konge var tårnbyggeriets meningsinnhold og tårnene materialiseringen av en pågående rivalisering, slik som i striden mellom biskop Pål av Hamar og Håkon Håkonsson mellom 1230 og 1260. Håndverkernes rolle i dette «spillet» ble vesentlig, da murerne kunne ta oppdrag på begge sider av konflikten. Slik det fremkommer, var materialiseringen av kongens og kir-

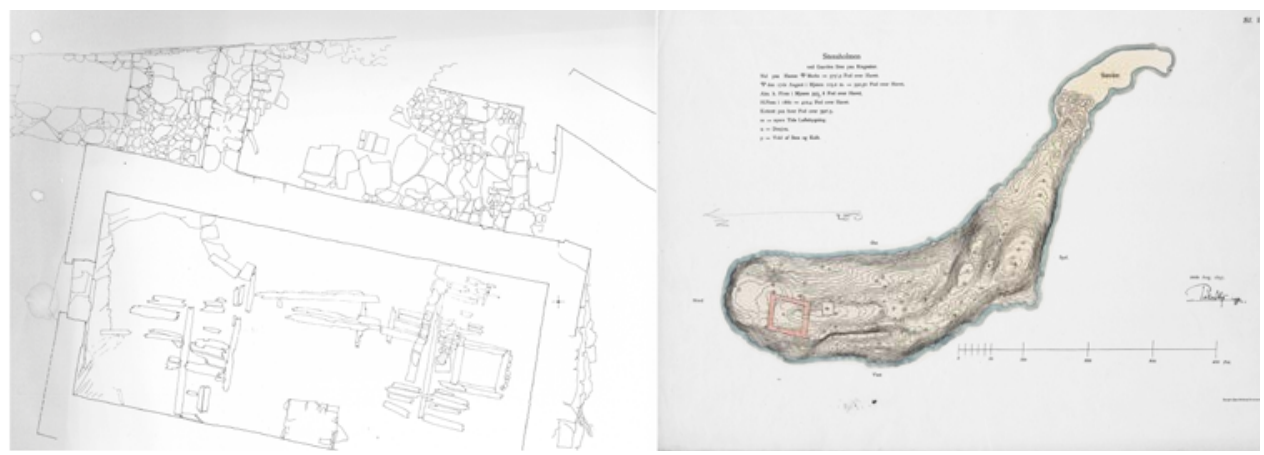

Figur 1. Sammenlignende plantegninger av tårnet i Hamar bispeborg og Blix' oppmålingstegninger fra 1897. Bygningene er av få bevarte frittliggende tårn fra middelalderens Norge. Illustrasjoner: Anno museum, avdeling Domkirkeodden og Blix (1897). 
kens makt avhengig av utførende håndverkere. De ble nøkkelpersoner både for Håkon Håkonsson og biskop Pål og senere for biskop Peter.

Bruk av komparative analyser i murverksstudier er i noen grad benyttet i arkeologiske analyser. Ole Egil Eide (1974, 2007:139) gir fruktbare eksempler på slike i sine studier av Clemenskirken i Oslo. Primært var Eides prosjekt å datere den toskipete Clemenskirken gjennom en sammenligning av murverk og stilistisk preg med Edmundskirken, som er en del av Hovedøya kloster. Gjennom en komparativ analyse av de to kirkenes skip, som viser samsvarende planendringer og muremåter, foreslåes det at kirkene kan ha vært oppført av felles byggherre/håndverkere (Eide 2007:149). Kirkene oppfattes også som samtidige, og er oppført i én kontekst, da slike toskipede kirker avviker fra øvrige norske middelalderkirker. Studien gir et godt eksempel på hvordan komparative analyser av muremåter, spesielt der disse sammenfaller, kan gi større kunnskap om håndverkere og regionalitet i norsk middelalder. Med utgangspunkt i Eides metodikk, som er en materiell analyse basert på Krautheimer, følger en komparativ murverksstudie av Hamar bispeborgs tårn, oppført av biskopene Pål og Peter, og av Håkon Håkonssons Mjøskastell. Analysen avsluttes med en diskusjon av tårnbygningene og deres materielle uttrykk sammenlignet med andre steinbygninger i Hamar bispedømme og i Norge for øvrig, for å vise håndverkernes regionale uttrykk knyttet til hamarbispens bygghytte

\section{Hamar bispeborgs frittliggende tårn}

Etter opprettelsen av Hamar bispedømme i 1152-1153 ble det etablert en residens for biskopen i tilknytning til domkirken. Hamar bispegård, slik vi kjenner den i dag, ble påbegynt på midten av 1200-tallet, og omfattet da en ringmur med sentraltårn, en sydfløy, borgstue, porttårn og hjørnetårn. Borgen ble senere, rundt 1450, forminsket og forsterket. Det ble da også bygget flere interne hus i utmurt bindingsverk for ulike funksjoner som matlaging og smiing (Sæther 2005). Bispeborgen skisseres og beskrives ut fra ruiner og spor i marken, av Gerhard Schøning (1942 [1775]:44) som del av hans reise gjennom Hedmarken i 1775, og nevnes i korte trekk av Vang-presten Nils Sverdrup (1803 [1707]:94) i 1707. I 1916 målte Daniel Dahl opp bispeborgen og beskrev den, og publiserte resultatene i Foreningen til norske fortidsminnemerkers bevaring Arbok samme år (Dahl 1916). Bispeborgen var på det tidspunkt en del av uthusbygningen på Storhamar gård, og i bruk som stall og fjøs. I 1946 kjøpte Hedmarkmuseet og Domkirkeodden uthuset, og utgravninger av borgen startet året etter. Utgravningene var ledet av Fischer, assistert av museets konservator Toralv Bleken-Nilssen og med Christie som oppmåler. Utgravningene ble gjennomført etter tidens metode, med fokus på murverk. Materialet er ikke publisert, men det finnes en rikholdig dokumentasjon bestående av feltdagbøker, foto, oppmålingstegninger, gjenstandsfunn og funnlister. Christie overtok utgravningene fra midten av 1950-årene. Senere ble nordøstre hjørnetårn og en bygning tolket som Hamar-kaupangens rådstue (Sæther 1990) gravet ut av Oldsaksamlingen og Domkirkeodden i 1981-1983 og 1986-1989. Bispeborgen er senere presentert og diskutert av Tor Sæther (1986, 2003, 2005).

En interessant bygningsdel i bispeborgen er et frittliggende tårn inne i borggården. Det er i dag en rektangulær ruin på 21 x 8 m utvendig målt, skåret ned i berggrunnen sentralt plassert i borggården (figur 2). Bruken av tårnet og dets innhold er gjort rede for rundt 1550 i Hamarkrøniken slik: «Hammer gårds tårn var muret jevnhøyt med det første tårn på dom- 


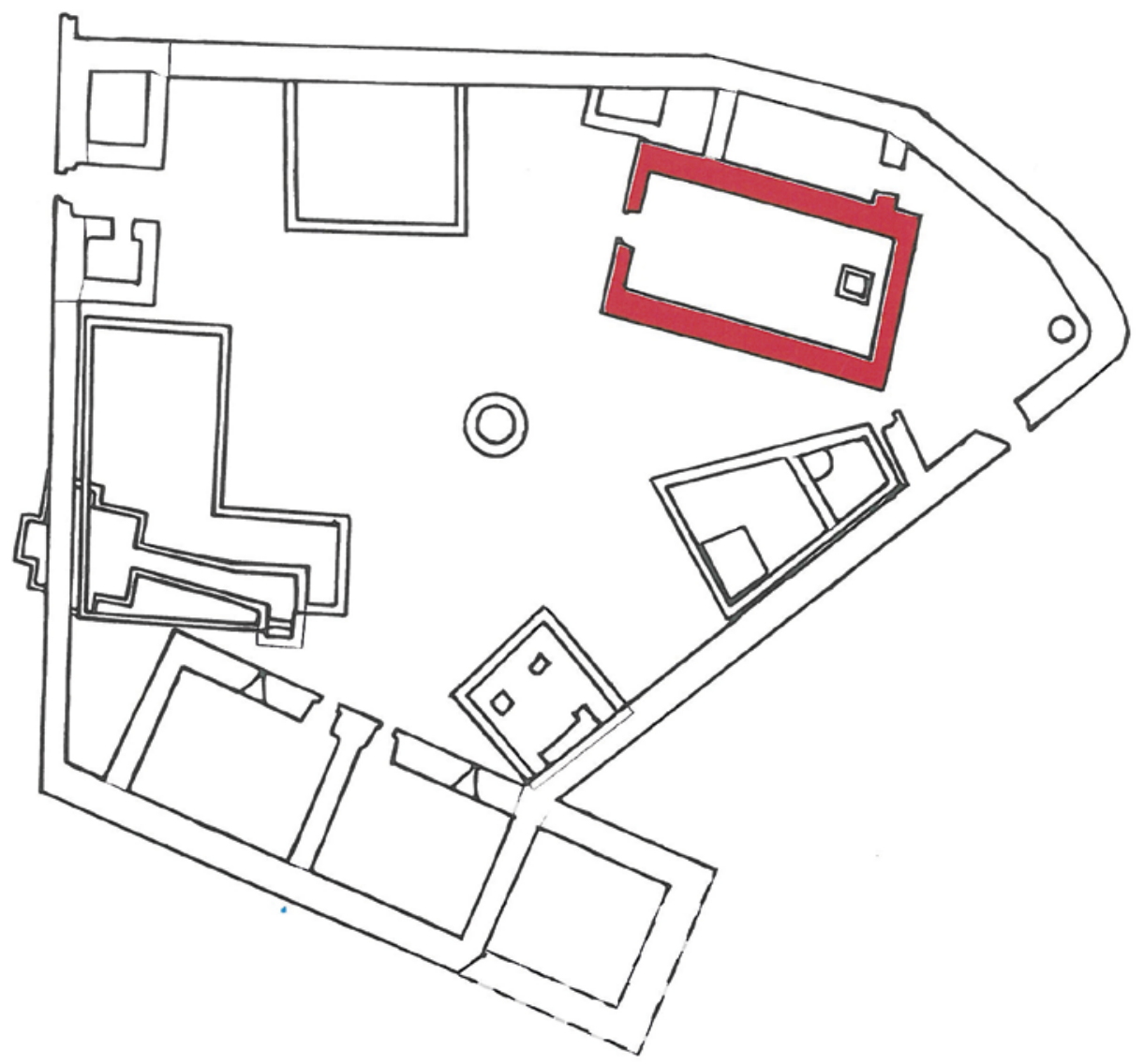

Figur 2. Hamar bispeborgs sentraltårn markert i rødt her i en 1450-situasjon.

Bygningsstrukturen er eneste kjente sentraltårn i norsk middelalderborger. Illustrasjon: Anno museum, avdeling Domkirkeodden.

kirken, slik at de kunne stå og tale med hverandre når som de talte litt høyt. I samme Hamar gårds tårn hadde det i gamledager vært bryggerhus, bakerhus, steikerhus og hvelvet kjeller med brønn i og mange skjønne kammer og våninger» (Pettersen 1986:23).

Ifølge biskop Jens Nilssøns Visitatsbøker og reiseopptegnelser 1574-1597 med opptegnelse over hamarbispene skal tårnet være oppført av Peder Danske, som var biskop på Hamar i 1433-1441 (Nielsen 1885:583). Meisling av eldre istandsatte sementfuger i forbindelse med istandsetting har muliggjort C14-dateringer (BETA-468440, 810 $\pm 30 \mathrm{BP}$ ) av organisk materiale fra sikre kontekster i murkjerner og mørtelanalyser. Bispeborgen er tidligere kun datert ut fra murverkets uttrykk og Jens Nilssøns beskrivelser, men vi har nå en absolutt datering til tidsrommet 1169-1270, som bekrefter tidligere antagelser om at byggherren var biskop Peter. Ifølge Nilssøn slik det er gjengitt i Nielsen (1885:580) skal Peter ha oppført bispeborgen på midten av 1200-tallet: «Peter reiste til Roma, der han ble ordinert til 
biskop, og da han vendte tilbake, begynte han å grunnlegge bispesetet/kapitlet i Hamar, der han døde og er begravet.»

Et annet moment som taler for en 1200-tallsdatering, er en runeinnskrift (N551) funnet på en kalksteinsblokk fra tårnet. Innskriften er forfattet i presens og lyder: «og det sier biskopen om det». Innskriften har en grammatisk form for e-runen som er benyttet fra slutten av 1200-tallet og på 1300-tallet. Men innskriften kan være risset tidligere. En studie gjort av Terje Spurkland (1994) viser at formen for p-rune som her brukes i buskup, er en invensjon som tas i bruk rett før 1175. Innskriften bør dateres til perioden 1175-1300. Tekstens datering støtter en datering av tårnet til biskop Peter, som døde i 1260. Den nye dateringen av tårnet bekrefter at bygningsdelen tilhører den første byggefasen av borgen. Dateringen muliggjør sikrere bruk av tårnets murverk og mørtler i komparative studier, som argument for regional steinbygging og håndverkermiljø i Hamar bispedømme på 1200-tallet.

I dag er kun tårnets kjeller bevart, og rester av tønnehvelvet er synlig i de øvre innvendige murvangene som heller innover i vestre ende. Tårnet er rektangulært og bygget opp av gotisk murverk i kalkstein med jevne skifteganger. Kistemurene er mellom 1,2 og 1,5 m brede. Det er brukt en del mindre pinningstein, slik det fremkommer av Christies oppmålingstegninger (figur 3). Senere istandsettinger med sement har visket ut disse bygningssporene, men eldre bilder og opptegninger gir et bilde av det originale murverket.

Steinstørrelsen er varierende, og det er brukt tuktet stein på mellom $10 \mathrm{og} 40 \mathrm{~cm}$ (figur 4). Ulike vindusnisjer er plassert på sørveggen. Funn fra utgravningen, slik det fremkommer av feltdagbøker og gjenstander, viser at vinduene hadde jernsprosser og glass. Inngangen til kjelleren finnes på vestveggen. Utgravningsdagbøkene viser slik at flere observasjoner fra Hamarkrøniken stemmer. Blant annet finnes doble gotiske fint huggede vindusomramninger fra øvre etasjer som viser at tårnet var høyt (figur 5). Vindusomrammingene viser samtidig at tårnet har hatt en representativ funksjon. Kjøkkenet har antagelig vært plassert i første etasje, med biskopens kammer for opphold, bespisning og soving plassert i etasjen over (Sæther 2005:63). Slik vindusnisjene antyder, kan øverste etasje ha vært benyttet som

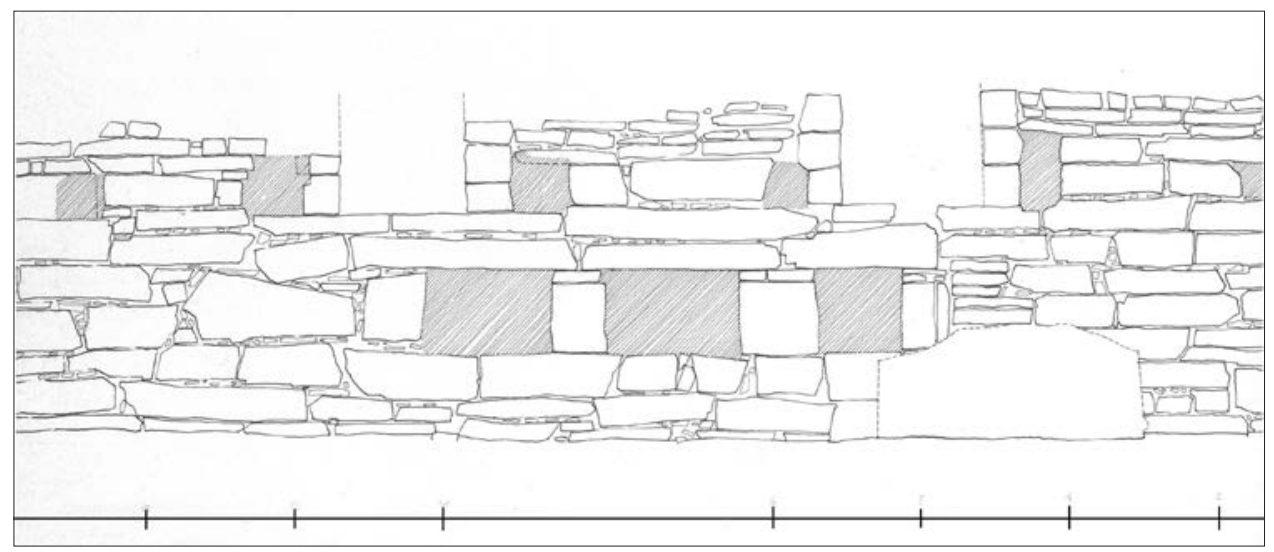

Figur 3. Murverk i Hamar bispeborgs sentraltårns nordre innervange. Dokumentert av Håkon Christie i forbindelse med utgravinger i Hamar bispeborg omkring 1960. Illustrasjon: Anno museum, avdeling Domkirkeodden. 


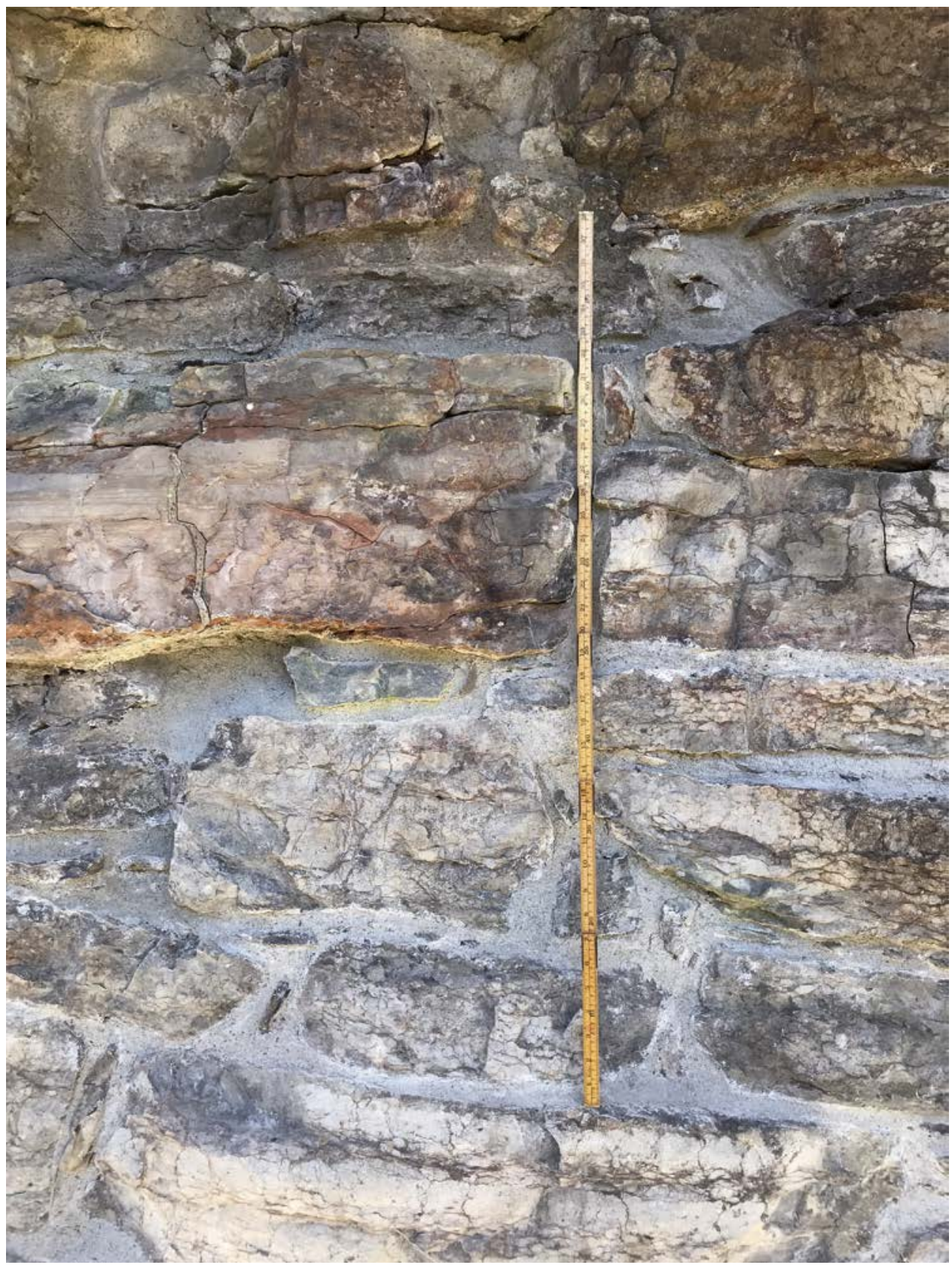

Figur 4. Ferdig istandsatt murverk fra bispeborgens sentraltårns nordre innervange.

Foto: Kristian Reinfjord. 


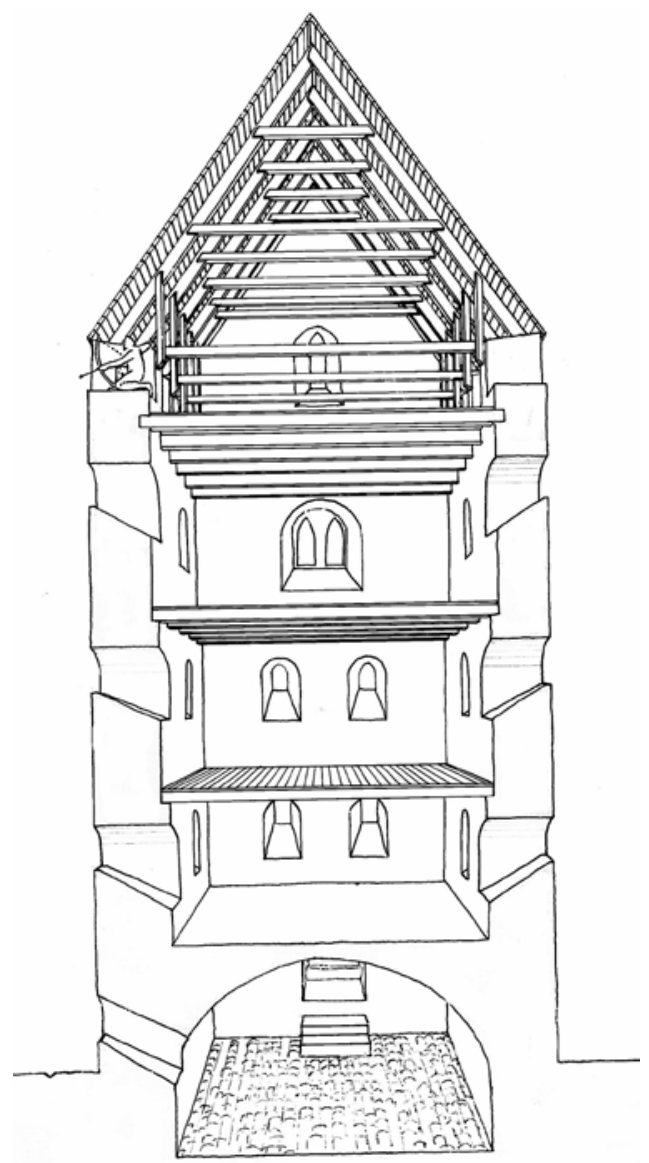

Figur 5. Rekonstruksjonstegning av tårnet basert på bygningsarkeologiske studier, funn av bygningsstein og beskrivelser $i$

Hamarkrøniken. Domkirkeodden dok-36195.

en sal/hall for representasjon og festlige anledninger.

I østre ende av kjellerrommet finnes brønnen som omtales i Hamarkrøniken. Tårnets inngang har ligget på kortveggen $\mathrm{i}$ vestre ende, hvor en tretrapp sannsynligvis har ledet ned til kjellerrommet. I flukt med bakkenivået synes rester etter anlegg for takbjelker. Om disse dateres til byggeåret, har kjelleren vært delt i to etasjer, og det er sannsynlig med tanke på hvelvingens høyde slik den fremkommer av det slake innoverlente murverket i de øvre delene av langveggene. Veggene i kjelleren har flere nisjer for lagring av verdifulle gjenstander som her kunne oppbevares frostfritt. For øviig ble slike kjellere ofte benyttet til oppbevaring av mat, vin eller øl. Steingulvet i tårnet er av kuppelstein, med et dreneringssystem slik krøniken forteller. Over steingulvet ble det under utgravningene funnet et tredekke av høvlede bord.

Det frittliggende tårnet i Hamar bispeborg er en distinkt bygningsdel som ikke finnes i landets øvrige steinbygninger, og en parallell i Mjøskastellet er interessant for diskusjonen omkring regionale håndverksmiljøer på Østlandet. Borgtårnet på Hamar bispeborg har ingen distinkte paralleller i noen skandinaviske bispeanlegg fra før 1300 (La Cour 1972; Lovén 1996). Heller ikke i det norske materialet som omfatter 17 bispeanlegg, finnes eksempler på frittliggende tårn, slik det fremkommer av Sæbjørg Walaker Nordeides (2003:136-157) gjennomgang av bispeseter under erkebispesetet Nidaros. Det er derfor naturlig å kikke på komparative eksempler regionalt, både blant verdslige og kirkelige anlegg, og Mjøskastellet peker seg ut, både stilistisk og kronologisk.

\section{Mjøskastellet: en regional rollemodell?}

Håkon Håkonssons Mjøskastell var en kvadratisk tårnbygning på 18 x 20 m, utvendig målt, strategisk plassert på en liten holme nordøst i Mjøsa ved et smalt sund, knapt to kilometer nordvest for Ringsaker kirke (figur 6). Bygningen er oppført i stein på holmens nordende, ikke på holmens høyeste punkt. Det tyder på at utsikten nordover var spesielt viktig. Også ferdselsveier mot øst og vest krysset hverandre ved Steinsholmen. Den sentrale beliggen- 
heten understrekes av bygdeborgen på Stein, bronsealderrøysene på Steinsholmen og tettheten av gravhauger i området. Mjøsa var en sentral kommunikasjonsåre på Østlandet i middelalderen, som det var viktig å kontrollere. Det kan ha vært motivasjonen for oppføringen av tårnet. Mjøskastellet nevnes i enkelte kilder, først i et pavebrev datert Perugia 5. oktober 1234, som forteller at Håkon Håkonsson (1217-1263) «har bygget et nytt kastell mot biskopens vilje» (DN I, nr 13). Biskopen som her nevnes er Pål, som var den syvende biskop av Hamar i perioden 1232-1251. I sagaen til den samme Håkon nevnes også kastellet: «Han lét gjere ei steinborg i Mjøsa på holmen ved Ringsaker, og hus i henne» (Thordsson 1963 [1265]:368). Hverken Fischer (1928) eller andre har vært i tvil om at denne ruinen er den som omtales i Håkon Håkonssons saga. Tårnet kan med bakgrunn i skriftlige kilder dateres temmelig nøyaktig. Og dateringen stemmer godt overens med utformingen av murverk og materialbruk. Senere ble tårnet benyttet av Magnus Lagabøte som fengsel, etter 1270. Tårnet nevnes i hans hirdskrå, hvor kastellet benyttes som statsfengsel, og hvor behandlingen av drapsmenn og fengselsstraff omtales: «Men fra Drammensfjorden og fra Telemark og helt vest til Rygjarbit, til Tønsberg, og fra Opplandene unntatt Romerike, til Mjøskastellet» (Imsen 2000:137). Nicolay Nicolaysen (1866:83) hevdet at Mjøskastellet tidlig ble revet ned, og at stein derfra ble benyttet til påbygging av Ringsaker kirke. Fischer (1928:3) hevder med utgangspunkt i hirdskråen at kastellet $\mathrm{i}$ alle fall sto på begynnelsen av 1400-tallet.

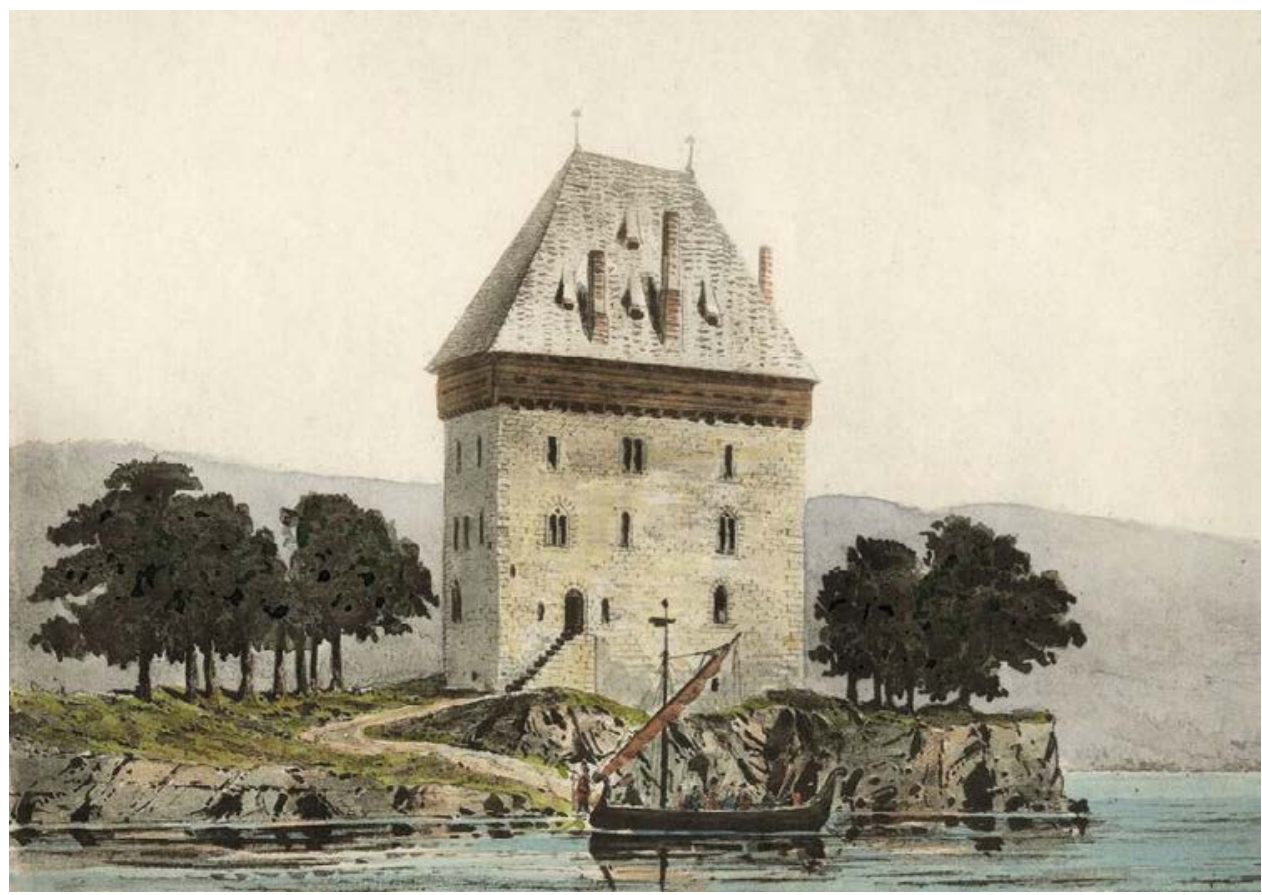

Figur 6. Peter Blix'rekonstruksjonstegning av Mjøskastellet i en fri tolkning. Etter Blix (1897). 
Mjøskastellet ble gjenoppdaget og beskrevet av Gerhard Schøning i hans Reise gjennem Hedemarken i 1775, hvor han identifiserer ruinen som Håkon Håkonssons kastell. Schønings beskrivelser av Mjøskastellet, basert på egne iakttagelser og lokale vitnesbyrd, viser at kastellet hadde fine detaljer. Han beskriver det slik:

Ved den nordre Ende er Holmen breedest og høiest, og paa det Sted har man derfor anlagt Fæstningen, av hvis Muure, blev mig berettet, at endnu for en føie Tiid siden, havde staaet høie Støkker og Levninger, hvilke vare uden paa besatte med polerede Pillarer, men nu er altsammen nedbrudt samt bortslæbt, og man seer her intet tilbage, uden af de nedbrudte Muure, som tildeels ere overvoxne, med høie Gran- og FurruTræer, hvor af kan sees, at endeel af Muurene maae, for længe siden, være afbrudte (Schøning 1942 [1775]:19)

Nicolaysen nevner også ruinen i sin Norske fornlevninger 1862-1866 med en kort beskrivelse. Bygningen ble undersøkt av arkitekten Peter Blix i 1896 og senere av Fischer i 1928. Begge gjorde observasjoner som er interessante i denne sammenheng. I senere tid har Norsk institutt for kulturminneforskning (NIKU) gjort et forprosjekt som utgangspunkt for fremtidig dokumentasjon av Mjøskastellet sammen med ruinen av Valdisholm (Meyer mfl. 2014). Blix' tegninger av murene er skjematiske med tanke på steinstørrelse, forbant og skifteganger. Murene er kistemurer og relativt regelmessige med tanke på hva vi forventer på Østlandets gotiske murverk (figur 7). Store og små steiner er benyttet om hverandre, men i jevne skifteganger. Steinene er noe tilpasset, og det er i liten grad brukt pinning. Murbredden varierer mellom 1,5 og 1,8 m. Kalken i fugene er oppsmuldret i yten, men det finnes gode muligheter for analyser av kalkens sammensetning inne i murene. Blix' plantegning (1897) viser skjevheter i bygningen, med spisse vinkler i nordøstre og sydvestre hjørner. Tårnet har lite trolig hatt disse skjevhetene opprinnelig. Synfaring av ruinen har ikke avdekket om dette er korrekt, men en grundigere oppmåling vil kunne avkrefte det. Det er ikke spor av dekorative elementer som sokkelfremspring eller overganger til fundamenter.

På syd- og østsiden finnes to vindusåpninger med synlig skiftemuring mot åpningen på begge sider, på sydsiden med en rundbuet åpning, den andre med en horisontal helle over. Sydsidens vindusåpning er om lag $20 \mathrm{~cm}$ bred utvendig. Høyden kan ikke bestemmes, men Fischer (1928:4) antok at den har vært cirka $70 \mathrm{~cm}$. Vindusåpningenes sider er av tuktet stein og ikke tilhugget som kvader. Fisher (1928:4) observerte rester av kalkpuss på vinduets overligger og på en del av steinene rundt vindusåpningen. Det ble ikke observert kalkpuss ved befaring av kastellet våren 2017. Flere steder er murene utbrutt eller sammenraste. Ved utgravningene i 1897 fant Blix flere fint tilhugne steiner fra vindusinnfatninger og døromramminger (figur 8). Steinene skal ha blitt etterlatt på stedet, men er ikke påvist i ettertid. Blix har inntegnet steinene i en rekonstruksjon som kan være troverdig, hvor steinenes utforming kan benyttes i en komparativ studie. Gjenfinning av steinene for studier av verktøyspor ville øke Mjøskastellets verdi som arkeologisk kilde ytterligere. Verktøyspor på eldre bygningsstein kan være med på å avgjøre produksjonstidspunkt og knytte ulike bygninger til håndverkermiljø. Spesielt interessante er sålebenkstein og stein fra dør- og vindusbuer med profiler, vinkler og bredder. Steinenes utforming og uttrykk kan knyttes til håndverkere gjennom sammenligninger med materiale fra Hamar bispeborg. Fischer (1928:7) skal også ha sett rester etter en ytre ringmur, men den er ikke påvist arkeologisk. Nye arkeologiske undersøkelser kan påvise en slik om den finnes; det ville gi en interessant parallell til Hamar bispegård. Vi vet også lite om kastellets interiør. Etasjeskiller i form av bjelker eller hvelv sammen med ytre ringmur, om en slik kunne påvises, ville være med på 


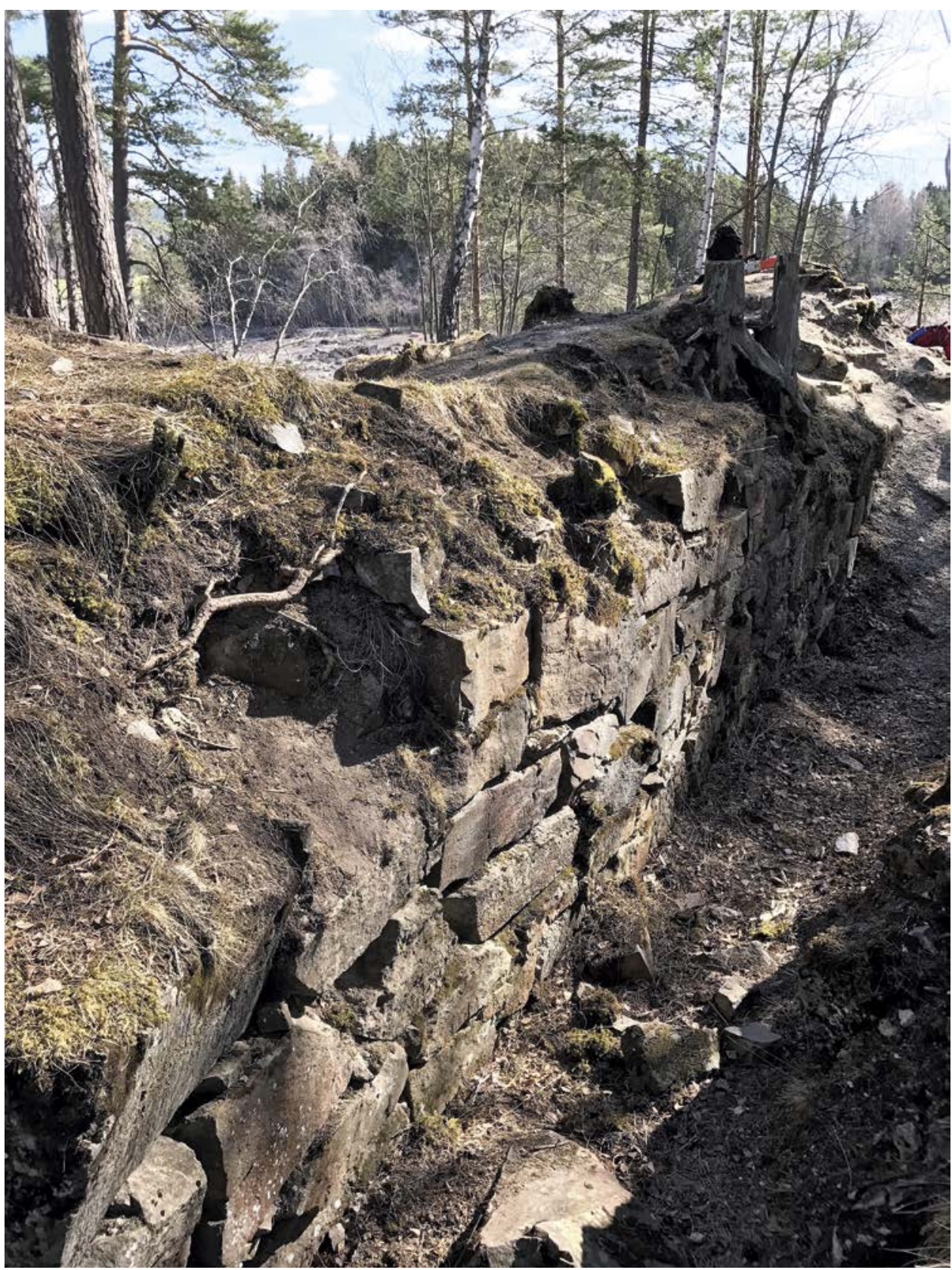

Figur 7. Gotisk murverk i Mjøskastellet. Jevne skifteganger i kalkstein, med utrast mørtel. Merk murverkets uttrykk sammenlignet med figur 4. Foto: Kristian Reinfjord. 
Fá Udgravninger pax Stenshulmen i Mjosen.

BL $2 X$ :

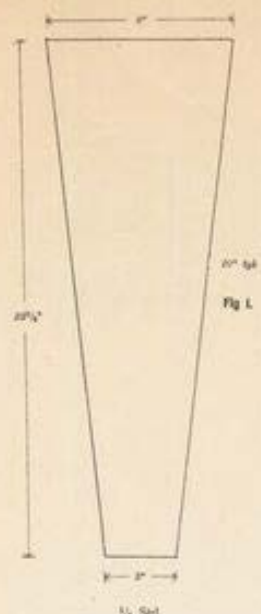

sode Ase 1505 .

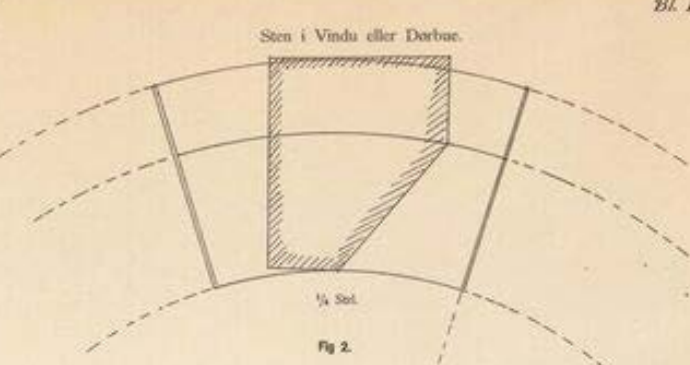

$\mathrm{ma}_{2}$

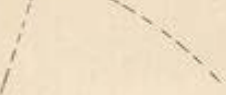

1
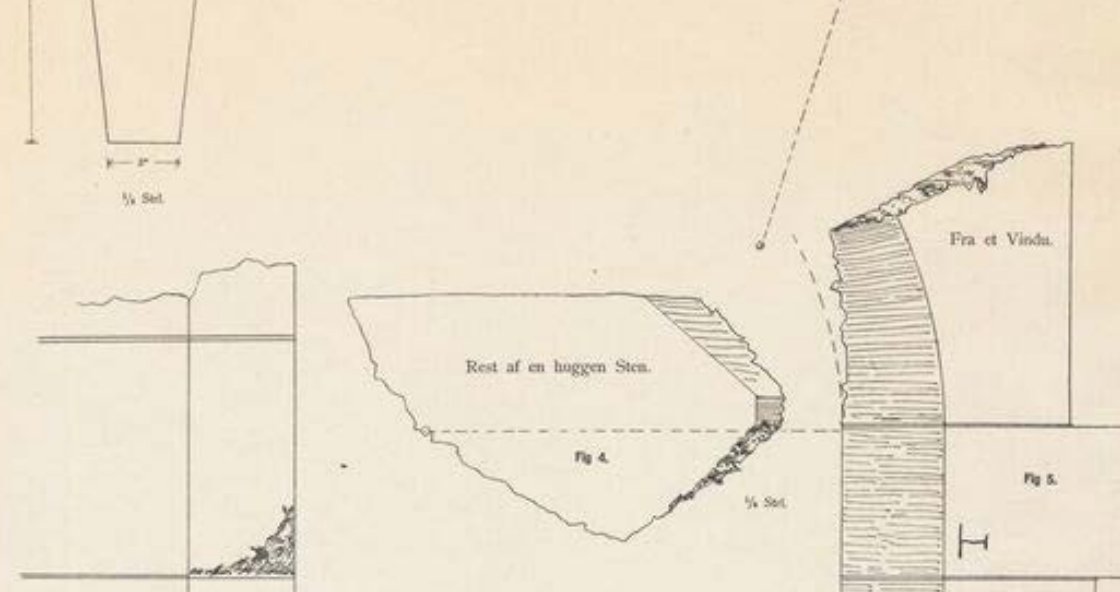

.

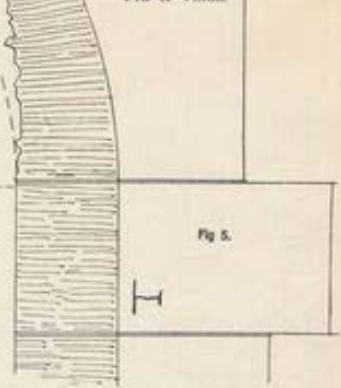

$\operatorname{mas}$
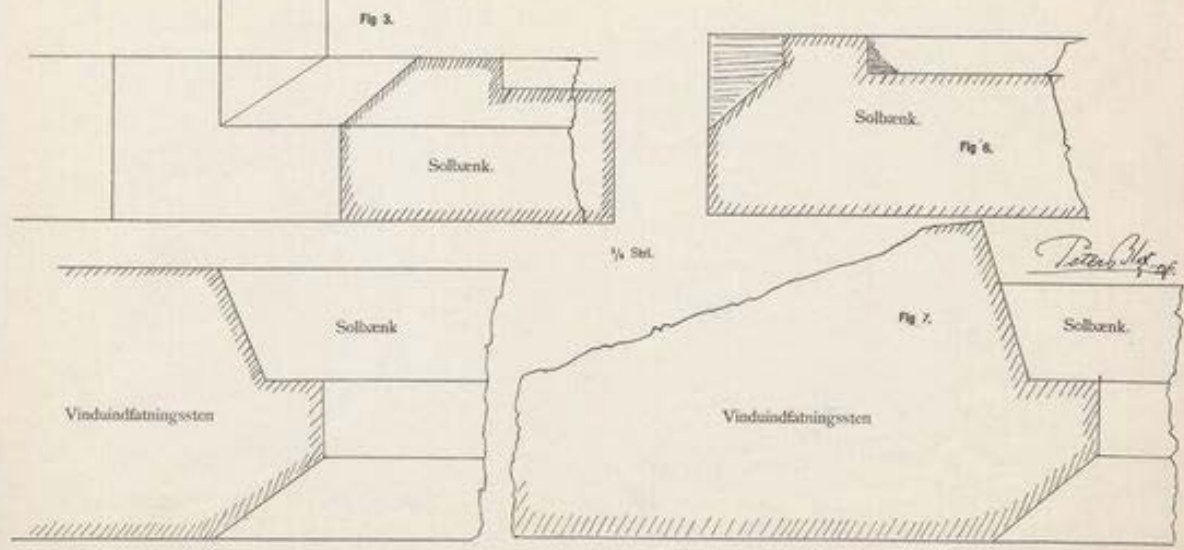

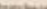

Figur 8. Peter Blix' rekonstruksjonstegninger av vindusnisjer fra Mjøskastellets øvre etasjer etter funn av såle- og omramningsstein. Etter Blix (1897). 
å styrke sammenligningsgrunnlaget mellom Mjøskastellet og Hamar bispeborgs tårn. Slik analysen ovenfor viser, kan tårnene knyttes sammen gjennom deres utforming, sammenfallende murverk og materialbruk. At Mjøskastellet er den eneste kjente parallell til bispeborgens frittliggende tårn, er med på å underbygge hypotesen om felles håndverkere eller felles påvirkning. Et kastell er en mindre, frittstående festning eller borg, en bygningstype som var svært lite utbredt i Norge i middelalderen. Kompetansen for bygging av slike fantes ved Hamar-biskopens bygghytte.

\section{Bygningselementer på Østlandet sammenlignet med øvrige Norge}

Ruinene etter bispeborgens tårn og Mjøskastellet fremviser en rekke påfallende likheter. Fischer (1928:3) tenker seg at byggingen av Mjøskastellet ble gjort ved at kongen kan ha sendt kyndige murere fra pågående arbeider i Tønsberg til rask bygging av Mjøskastellet, og tolker arbeidene som del av en «samlet befestningsplan» sammen med byggingen av festningene i Konghelle, Tønsberg og Oslo og Valdisholm i Glomma. På bakgrunn av det arkeologiske materialet virker det rimelig å anta at murhåndverkere fra Hamars bygghytte er benyttet. Strukturene er relativt likt utformet med tanke på at de begge er oppført som tårn, en sjelden bygningstype i middelalderens Norge. Bygningenes uttrykk når det gjelder forholdet mellom lengde og bredde utmerker seg. Av bygningsdetaljer er det kun kjent gotiske vindusomramminger fra tårnbygningene. På Mjøskastellet er det bare funnet fragmenter av slike steiner, og det er kun mulig å studere dem i Blix’ oppmålingstegninger (1897). Vindusnisjene fra Hamar er godt bevart og dokumentert. Ut fra materialets beskaffenhet synes falser og kurvaturer relativt like. Tårnbygningene er oppført innenfor en periode i første halvdel av 1200-tallet, mellom 1230 og 1250, og inngår i en felles historisk kontekst. Begge tårn benytter gotisk murverk i kalkstein med jevne skifteganger og liten grad av pinning. Steinene er tuktet i lik grad, og mørtelfugenes bredder og uttrykk er sammenfallende. Det samme uttrykk har også murverket i Hamar domkirkes utvidede kor og korkapell, som dateres til tidlig 1300-tall (Pedersen 1999:197).

Utgravningene knyttet til domkirken viser at perioden fra 1250 var en aktiv tid for Hamar-biskopen og hans bygghytte. Det kan spores i byggearbeider på kirken, spesielt i form av korutvidelsen, ombygging av tverrskipene og endringer i kirkegårdstopografien (Pedersen 1999:188, 193). Korutvidelsen dateres til tiden rundt 1310, og bygningsdelen benytter gotisk murverk. Her er skiftegangene noe mer ujevne enn dem vi finner i bispeborgen, men det er samtidig benyttet gjenbrukt stein fra den romanske perioden (Pedersen 1999:197). De er lagt inn for å passe i veggene, og det er kompensert med ujevnere skift og pinning for å nytte seg av denne blåaktige, fint tilhogde mjøskalksteinen. I Hamar bispeborg er flere murbygninger og murverk lik tårnet og Mjøskastellet. Spesielt tilsvarende i skifteganger, steinstørrelse og mørtelbruk er bispeborgens sydfløy, som vi har C14-datert til peri-

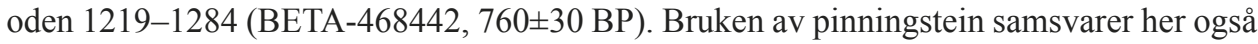
med det vi ser i tårnbygningen. Dateringen fraviker noe fra tidligere bygningsarkeologiske vurderinger, som gir sydfløyen en noe senere datering enn tårnet (Sæther 2003:432), basert på bygningenes plassering i forhold til domkirken. Sydfløyen er for øvrig plassert parallelt med tårnet.

En samtidig regional parallell fra Hamar bispedømme er steinhuset på Gran, en rektangulær (12,5 x 8 m utvendig målt), høy steinbygning på to etasjer med hvelvet kjeller. Huset 


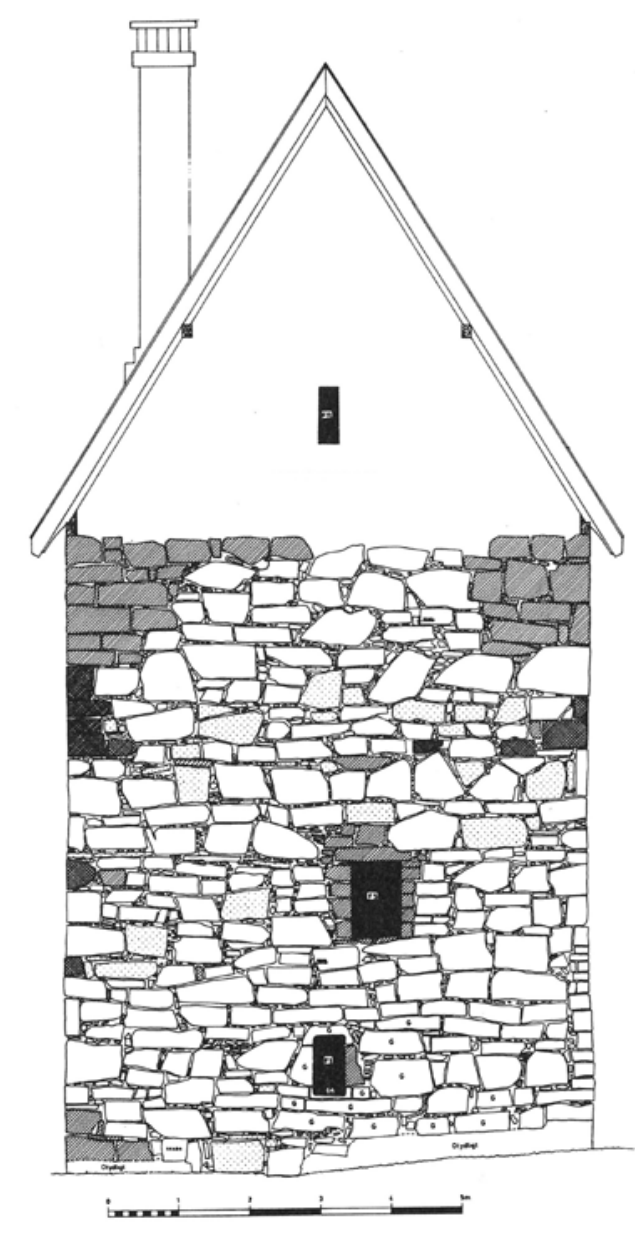

Figur 9. Steinhuset på Grans nordre gavlvegg. Illustrasjonen viser originalt gotisk murverk $i$ hvitt. Her sees jevne skifteganger med tilsvarende steinstørrelser $i$ kalkstein som $i$ Hamar bispeborg. Etter Rosborn (1991:3). ligger på prestegården, noen hundre meter vest for søsterkirkene på Gran, Hadeland. Steinhuset på Gran fra andre halvdel av 1200-tallet, samsvarer i murverksutforming med Mjøskastellet og tårnet $\mathrm{i}$ bispeborgen (figur 9). Sven Rosborn (1991:7) har datert byggearbeidene på bakgrunn av ombyggingen av Nikolaikirken på Gran, for steinhuset har gjenbrukte kvaderstein fra kirken. Korutvidelsene på Søsterkirkene samsvarer i muruttrykk og detaljer med steinhusets fjerde fase, og det er trolig at samme håndverkere har utført arbeidene. Også kjelleren i anlegget er karakteristisk for Mjøsbygdene, slik den fremstår på prestegårdene på Ringsaker, Hoff og kanskje Norderhov på Ringerike. Kjellerne er sett i sammenheng med steinhuset på Gran, og en tenker seg at strukturene har tilhørt middelalderske prestegårdsanlegg, med forbilder i bispeborgen i Oslo og Hamar og hamarbispens anlegg på Storøya i Tyrifjorden (Wibe Müller 1979:243). Tilsvarende steinkjeller finnes også under bispeborgen og i ruinene etter katedralskolen på Domkirkeodden. Samtidig ser bruken av slike steinkjellere ut til å være et østnorsk fenomen.

I kontrast til gotiske murverk i murbygningene rundt Mjøsa står blant annet erkebispens residens på Nordnes i Bergen, hvor de eldste delene er datert til for 1280 (Kristoffersen 1988:166) og karakteriseres av store, flate steiner på høykant. Her er stor utbredelse av pinning og lite markerte skifteganger. Dette murverket kan minne litt om Hamar bispeborgs østre ringmur, som antagelig er oppført omkring 1450.

Den skiller seg vesentlig fra de øvrige murrester på Hamar, og står i kontrast til byggearbeidene her på 1200-tallet.

Sammenhenger mellom tidligere steinbygninger på Østlandet, og spesielt romanske kirkebygg, underbygger hypotesen om et regionalt håndverksmiljø. Spesielt sammenfallende er en gruppe basilikaer i regionen med homogen utforming. I Norge finnes 20 treskipete basilikaer, en form primært knyttet til domkirkene (Pedersen 1999:185). Av dem utgjør seks kirker, inkludert Hamar domkirke, en uniform gruppe, tilsynelatende bygget etter ett mønster. I tillegg til Oslo og Hamar domkirker består gruppen av kirkene i Gamle Aker, 
Gran på Hadeland, Hoff på Toten og Ringsaker på Hedmarken. I tillegg finnes to sognekirker, Tjølling i Vestfold og Laurentiuskirken i Tønsberg, og Mariakirken i Bergen, med treskipet basilikagrunnplan. Kirkene i Vestfold og Bergen har et annet preg enn østlandsbasilikaene. Alle kirkene er oppført fra andre halvdel av 1100-tallet og første del av 1200-tallet, men har et arkitektonisk og håndverksmessig fellespreg (Christie 1969:112).

Den østlandske basilikaformen, slik den forekommer i Oslo og Hamar bispedømmer, danner et mønster i utforming, materialbruk og håndverk (Ekroll 2004:65). Kirkene skiller seg fra de øvrige middelalderkirkene, samtidig som tettheten av steinkirker er stor på Østlandet. Disse bygningene er større enn landets øvrige steinkirker og danner en heterogen gruppe, slik plantegningene viser (figur 10). Spesielt er de fire sognekirkene på Toten, Hadeland, Ringerike og Ringsaker relativt like, og etterligner Hamar domkirke i stor grad. Den østnorske basilikatypen er romansk treskipet med lave midtskip. Koravslutningene har apsider, og søylene som danner midtskipet, er ikke monolittiske, men oppbygget av mindre steiner som gir tykkere arkader. Ingen av kirkene i Hamar bispedømme ser ut til å ha hatt tverrskip, men de hadde høye midttårn. Ingen av kirkene rundt Mjøsa hadde noe særlig dekor, og portalene er rene, uten figurutsmykning. Også i målestokk, stein- og mørtelbruk er kirkene sammenfallende.

Ekroll (2004:67-68) tolker østlandsbasilikaene som et resultat av samarbeid mellom konge- og kirkemakt i Hamar bispedømme på slutten av 1100-tallet. Samarbeidet mellom de to statsmaktene på Østlandet står i kontrast til forholdene i Vest- og Midt-Norge, hvor Sverre og birkebeinerne sto i sterk opposisjon til de geistlige. Basilikaene var en manifestasjon av samarbeidet mellom kongen og kirken, slik den fremkom på Østlandet, i et felles byggeprogram «for å utforme kyrkjer som blir fysiske uttrykk for møtet mellom himmel og jord, Gud og menneske, verdsleg og åndeleg makt i den bispestyrte kyrkja, som var ein del av den universelle kyrkja styrt av paven» (Ekroll 2004:69). Østlandsbasilikaen er resultat av et unikt samarbeidsprosjekt i norsk middelalder, og viser at håndverkere i Hamar bispedømme har påtatt seg oppdrag på vegne av kongen og kirken, og at det i regionen var tradisjon for slike samarbeidsformer. Senere, på biskop Påls og Håkon Håkonssons tid i første halvdel av 1200-tallet, var neste generasjon murere bevisst disse samarbeidsformene og kunne påta seg prosjekter for begge parter, også som del av en konflikt slik den materialiseres i byggingen av Hamar bispeborgs sentrale tårn og Mjøskastellet.

En annen gruppe bygningselementer fra steinarkitekturen som underbygger eksistensen av regionale håndverkermiljøer, er de bevarte takkonstruksjonene i tre fra middelalderen. Takkonstruksjoner i tre er bevart i 16 komplette og 20 delvis bevarte tilfeller i Norges steinkirker fra middelalderen. Materialet utgjør den tredje store gruppen av trekonstruksjoner fra middelalderen etter stavkirkene og tømmerhusene, og spredningen i materialet følger spredningen av steinkirkene. Konsentrasjoner finnes derfor i Trøndelag og på Østlandet (Storsletten 1993:14). Takkonstruksjonene faller inn under to hovedkategorier, hvor hovedområdene viser spesifikk utforming av takstoler. Hver takstol er konstruert i en typisk middelalderteknikk spretteljet furu med parallelle sperrer med en avstand på 50-80 cm. Et gjennomgående særtrekk for Østlandets takkonstruksjoner er bruken av gjennomgående bindebjelker. I motsetning til trøndelagskirkenes stikkbjelker og deres åpne himling har østlandskirkene flat himling med loft over skipet. Ola Storsletten (1993:19) tenker seg at det kan være en sammenheng mellom utførelsen av takstolene og ønsket om å konstruere et loft for oppbevaring, blant annet fordi det finnes lysåpninger til loftet i alle bevarte tak. 


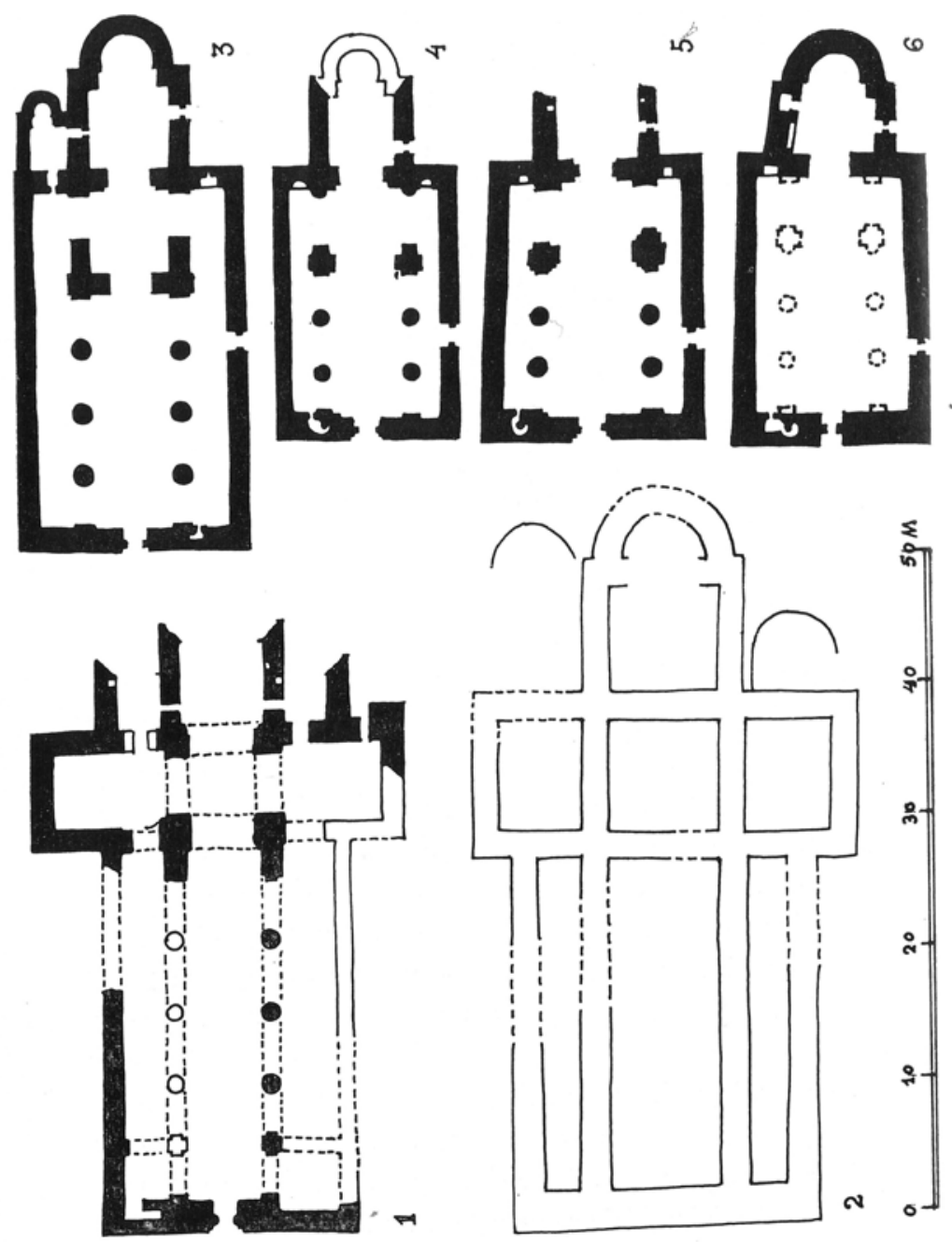

Figur 10. De østnorske basilikaene tilhører en homogen gruppe middelalderkirker med tanke på utforming i grunnplan, stil og materialbruk. Sognekirkene finner modeller i katedralene ved bispesetene. 1) Hamar domkirke, 2) Halvardskatedralen, 3) Gamle Aker kirke, 4) Nikolaikirken på Gran, 5) Ringsaker kirke, 6) Hoff kirke. Etter Christie (1969:114).

Det er bevart takkonstruksjoner i ni østlandskirker i stein: Rygge og Rødenes i Østfold, Skoger gamle kirke i Buskerud, Tingelstad, Ulnes og Vestre Slidre i Oppland, Nes, Bø, Seljord og Kviteseid i Telemark. I Storslettens rapport (1993:26) er to takkonstruksjoner fra Østlandet dendrodatert, Nes til 1181-1182 og Tingelstad til 1264. Til tross for sprikende dateringer i takverk med lik utforming er begge kirkene utført i romansk stil. Det kan vise at regionen hadde en innarbeidet måte å utforme takkonstruksjoner på både på 1100- og 1200-tallet. De fleste av kirkene med bevarte takkonstruksjoner faller inn under 
Hamarbispens håndverkerregion. Takene kan dermed bidra til å utdype regionenes særegne uttrykk. Bygningene oppført på 1200-tallets Østlandet, hvor kongen og kirken hadde tradisjon for allianser, viser likhetstrekk. Detaljer i planer, murer og dekor peker i samme retning.

\section{Et regionalt håndverksmiljø på Østlandet i middelalderen?}

Ved nye studier av eldre utgravningsmateriale, både fra Hamar på 1960-tallet, Mjøskastellet i 1896 og andre, mener jeg å kunne observere indikasjoner på et regionalt håndverksmiljø i Hamar bispedømme. Både i steinbruk, murhåndverk og stilistisk utforming korresponderer de utvalgte bygningene bra i en komparativ analyse. Begge strukturer, kastell og borgtårn, har gotiske kistemurer av lokal kalkstein, og er utformet kvadratisk med tilsvarende utformede vindusnisjer. Murverket er unisont med tanke på skifteganger, steinstørrelser og fugenes bredder og tykkelser. På bakgrunn av det foreslår jeg at begge tårn ble oppført av de samme byggmesterne, som har etterlatt homogene spor i Østlandets steinarkitektur på 1100- og 1200-tallet. Samtidig vises regionale forskjeller knyttet til middelalderens arkitektur og håndverk blant annet gjennom: distinkte trekk i steinkirkenes stilistiske utvikling, steinbruk i ulike landsdeler og de karakteristiske typer takkonstruksjoner. Til tross for konflikter mellom konge og biskop er det interessant å observere påfallende likheter i regional steinbruk og håndverksteknikk på 1200-tallet. Likhetene understreker håndverkernes rolle i middelalderen og hvordan regioner konsolideres geografisk gjennom materiell kultur. Et annet aspekt som ennå ikke er diskutert, er fraværet av steinhuggermerker i Hamar bispedømme, mens vi finner en rekke eksempler på slike i blant annet Trøndelag og miljøet rundt Nidarosdomen. Kanskje kan det, sammen med de ovenfor nevnte aspekter, tas til inntekt for at utviklingen av steinarkitekturen i Hamar bispedømme sprang ut fra et regionalt håndverkermiljø knyttet til Hamar-biskopens bygghytte på 1200-tallet.

\section{Note}

1 In territorio eiusdem ecclesie, quam omnio niteris ancillare, de novo quodam castrum invito ipso episcopo construixisti, eam quibusdam terris spolians.

\section{Summary \\ Regional stonemason environments in Medieval Hamar diocese}

The Hamar bishopric established in 1152-1153 saw large building activity after 1200 . Buildings put up in stone were atypical nationally, but the Hamar bishop was an active entrepreneur in the period 1250-1350. Based on stonework, material use and stylistic parameters the present article argues that these buildings were a result of a unified stonemason milieu controlled by the bishop. The argument is based on comparative analyses of building features of churches and other stone buildings connected to the ecclesiastical environment in general and an analysis of two selected tower buildings: the central tower of the bishop's castle at Hamar and the Mjøsa citadel erected by King Håkon Håkonsson. Despite the conflict between the king and bishop, it is suggested that both buildings, based on mason technique and design, were the work of the same masons. 


\section{Litteratur}

Baug, Irene

2016 Lokalsamfunn, regionar og nettverk i mellomalderen - ulike arkeologiske tilnærmingar. Viking 79:155-174.

Blix, Peter

1897 Undersøgelser paa Valdisholm i Glommen i Eidsberg og paa Stensholmen i Mjøsen. Morten Johannesen bogtrykkeri, Kristiania.

Brendalsmo, Jan

2015 Hamar bispedømmes utstrekning i middelalderen. I Norske sigiller fra middelalderen Bind 4. Geistlige segl fra Hamar bispedømme, redigert av Brita Nyquist, s. 33-52. Riksarkivet, Oslo.

Christie, Håkon

1969 Østnorske basilikaer. Kirkespeilet, Arbok for Oslo bispedømme 1969:111-115.

Dahl, Daniel

1916 Hamar bispegard. Foreningen til norske fortidsminnesmerkers bevaring. Arbok 1916:50-67.

DN: Diplomatarium Norvegicum. Oldbreve til Kundskab om Norges indre og ydre Forhold, Sprog, Sloegter, Sader, Lovgivning og Rettergang i Middelalderen. Elektronisk dokument, http://www. dokpro.uio.no/dipl_norv/diplom_felt.html, besøkt 19. januar 2018.

Eide, Ole Egil

1974 De toskipede kirker $i$ Oslo: et fors $ø$ k på redatering og opphavsbestemmelse med utgangspunkt $i$ de siste utgravninger i Clemenskirken. O.E. Eide, Bergen.

2007 Om muremåter og kirkedateringer i 1100-tallets Oslo. Foredrag holdt i Oslo Ladegård 25.4.2006 under tittelen «Clemenskirken 35 år etter». Collegium Medievale 20:137-168.

Ekroll, Øystein

1997 Med kleber og kalk: norsk steinbygging i mellomalderen. Det Norske Samlaget, Oslo.

2004 Hamar - det basilikale bispedømet. I Kaupang og bygd 2004. Hamar bispestol 850 år, redigert av Conrad Krohn, s. 13-70. Kaupang og bygd 2004. Hedmarksmuseet og Domkirkeodden, Hamar historielag, Hamar.

2008 Steintyper og steinbygging i middelalderen. Fortidsminneforeningens årbok 2008:27-35.

Eriksson, Anna-Lena

1995 Maktens boningar: norska riksborgar under medeltiden. Almqvist \& Wiksell International, Stockholm.

Fischer, Dorothea

1965 Steinhuggermerkene. I Domkirken i Trondheim. Kirkebygget i middelalderen, bind 2, redigert av Gerhard Fischer, s. 529-548. Forlaget Land og kirke, Oslo.

Fischer, Gerhard

1928 Mjøskastellet. Undersøkelse 25. juni 1928, vedlagt 10 fotografier og en oversiktsplan. Domkirkeoddens arkiv, Hamar.

1951 Norske kongeborger, bind 1. Norske minnesmerker, Cappelen, Oslo.

Hommedal, Alf Tore

1999 Hamarbiskopens gard på Storøya i Tyrifjorden. Fra kaupang og bygd 1999:7-22.

Imsen, Steinar

2000 Hirdloven til Norges konge og hans håndgangne menn: etter AM 322 fol. Riksarkivet, Oslo.

Krautheimer, Richard

1942 Introduction to an «Iconography of Medieval Architecture». Journal of the Warburg and Courtauld Institutes 5:1-33.

Kristoffersen, Siv

1988 Erkebispegården i Bergen - fyrsteresidens og handelshus. Fortidsminneforeningens årbok 1988:163-177.

Kühtreiber, Thomas

2014 The Investigation of Domesticated Space in Archaeology - Architecture and Human Beings. I Dwellings, Identities and Homes. European Housing Culture from the Viking Age to the 
Renaissance, redigert av Mette Svart Kristiansen og Kate Giles, s. 39-51. Jutland Archaeological Society, Aarhus University Press, Aarhus.

La Cour, Vilhelm

1972 Danske borganlceg til midten av det trettende århundrede bind I-II. Nationalmuseet, København. Lidén, Hans-Emil

1974 Middelalderen bygger $i$ stein. En innføring $i$ steinhugger- og murerhåndverket $i$ Norge $i$ middelalderen. Universitetsforlaget, Oslo.

1981 Middelalderens steinarkitektur i Norge. I Norges kunsthistorie, bind 2, Høymiddelalder og Hansa-tid, redigert av Knut Berg, s. 7-125, Gyldendal Norsk Forlag, Oslo.

Lovén, Christian

1996 Borgar och befästningar i det medeltida Sverige. Kungl. Vitterhets Historie och Antikvitets Akademien, Antikvariska serien, vol. 40. Stockholm.

Meyer, Regin, Lars Gustavsen og Ole Risbøl

2014 Forprosjekt: dokumentasjon, status og muligheter for Mjøskastellet og Valdisholm. NIKU Oppdragsrapport 100/2014. Norsk institutt for kulturminneforskning, Oslo.

Nicolaysen, Nicolay

1866 Norske fornlevninger: en oplysende fortegnelse over Norges fortidslevninger, celdre enn reformationen og henførte til hver sit sted. Foreningen til norske fortidsminnesmerkers bevaring, Kristiania.

Nielsen, Yngvar

1885 Biskop Jens Nilssøns visitatsbøger og reiseoptegnelser 1574-1597, udgivne efter offentlig foranstaltning ved Yngvar Nilelsen, A.W. Brøggers bogtrykkeri, Kristiania.

Nordeide, Sæbjørg Walaker

2003 Erkebispegården $i$ Trondheim. Beste tomta $i$ by'n. Norsk institutt for kulturminneforskning, Trondheim.

Pedersen, Ellen Anne

1999 Tusen års historie i kirkegårdens dyp: fra utgravningene ved Hamar Domkirkeruin 1988-1992. Universitetets Oldsaksamlings Arbok 1999:177-204.

Pettersen, Egil

1986 Hamarkrøniken. Alvheim og Eide, Øvre Ervik.

Reed, Stan

2005 Hamar Cathedral Ruin. Archaeological investigations 1996-1998. NIKU Rapport 6. Norsk institutt for kulturminneforskning, Oslo.

Rosborn, Sven

1991 Det medeltida stenhuset på Gran i Hadeland, Norge. Vigga-Trykk bok og aksidenstrykkeri, Jaren.

Schøning, Gerhard

1942 [1775] Reise gjennem Hedemarken 1775. Særtrykk av Hamar Stiftstidende, redigert av Leif Midthaug. Hedmark slektshistorielag, Hamar.

Spurkland, Terje

1994 K and P: One Grapheme or Two? I Proceedings of The Third International Symposium on Runes and Runic Inscriptions. Grindaheim, Norway 8-12 August 1990, redigert av James Knirk, s. 269-278. Uppsala universitet, Uppsala.

Stigum, Hilmar

1967 Murer. I Kulturhistorisk leksikon for nordisk middelalder: fra vikingetid til reformationstid. Bind XVII, redigert av Georg Rona og Allan Karker, s. 18-20. Rosenkilde og Bagger, København.

Storsletten, Ola

1993 Takverk $i$ steinkirker fra middelalderen. FOK-programmets skriftserie, vol. 5. Program for forskning og kulturminnevern. Norges forskningsråd, Oslo.

Sverdrup, Nils

1803 [1707] Opptegnelser. Taarups Magazin for Danmark og Norges beskrivelse II. 


\section{Svanberg, Jan}

1983 Medeltida byggmästare. Carmina, Uppsala.

2013 Medeltida byggmästare i Norden. Atlantis, Stockholm.

Sæther, Tor

1986 Bispegården fram i lyset. Fra hammer gård til Hamarhus slott - utviklingen av et bispegårdsanlegg. Fortidsminneforeningens årbok 1986:45-62.

1990 Et nyutgravd stykke av Hamars middelalder. Fra kaupang og bygd 1990:7-28.

1998 Hamar domkirke: En byggeplass i 430 år. I Vernebygg over en ruin, redigert av Kjell Lund, s. 55-76. Hedmarksmuseet og Domkirkeodden, Hamar.

2003 Ruinene av Hamar bispegård i lys av arkeologiske anlegg i Trondheim. I Ecclesia Nidrosiensis 1153-1537. Søkelys på Nidaroskirkens og Nidarosprovinsens historie, redigert av Steinar Imsen, s. 425-444. Senter for middelalderstudier, NTNU. Tapir akademisk forlag, Trondheim.

2005 A Short History of Medieval Hamar. Domkirkeodden, Hamar.

Thordsson, Sturla

1963 [1265] Soga om Håkon Håkonsson. Oversatt av Kristian Audne. Det Norske Samlaget, Oslo.

Wibe Müller, Inger Helene

1979 Stenhuset og Nikolaikirken på Gran: en arkitektonisk manifestasjon av en mektig prost. I Universitetets Oldsakssamling 150 år, Jubileumsbok 1979, redigert av Irmelin Martens, s. 243-248. Universitetets Oldsakssamling, Oslo. 